spots of red and black upon particular parts, were exceedingly bright and beautiful. When one compared the whole appearance to that of a clean fish, it was wretched and disagreeable; it was Iank; the belly empty, flabby, and of a dirty yellow; the jaws at a considerable distance in the mi..dle, the under jaw with a large protuberance standing perpendicular upon the extremity; the upper jaw with a hole almost quite through (and I am told in some quite through), in which, when the jaws were shut, the protuberance lodged. Not one fin entire; the scales and skin being in many places destroyed, presented the appearance of foul ulcers. The gills. were full of the Lernaa salmonee; such salmon are called Kipper, or foul fish.

The cruves in the river Devron are (following the windings of the river), about a mile and a half from the sea. In the sandy places below the cruves, where there is a sufficient depth of water, a great many salmon spawn. In those places they are seen raising considerable hills of sand, probably to cover and protect the spawn. ${ }^{1}$ They are likewise seen frequently pushing and striking one another; and the fishermen assert that they have many battles : their conjecture is that the battles are occasioned by the males endeavouring to get at the spawn in order to devour it, and the females endeavouring to defend it. About these hills they remain during the winter, and until the young fry appear, unless forced off by a torrent, probably in order to keep the hills in repair and to defend the spawn from the many enemies ready to attack it. Oucre,-Are not the form of the jaw;, the foul ulcers in the skin, and the destruction of the fins owing to the above-mentioned operations? Quare, - If salmon spawned in the sea, would they not be found more or less in the condition of kipper? But in this condition they are never found out of the rivers.

Linnæus says of the LERNEA Salmonea: "Habitat in branchiis salmonum; ergo etiam marina:" this latter is certainly a mistake; for these Lernaa are never found with us out of the rivers; and several sensible fishermen have assured me, that salt water proves absolute destruction to these animals.

Salmon, at a certain time during their stay in the sea, are infested by another animal of that genus, called by Linneus Mono. CULUs, which is as really a marine, as the other is a fresh-water animal. This species seems to me to be undescribed by authors and very distinct from the $M$. piscinus of Linneus, which it in some measure resembles. In a few hours after a salmon has entered the river, not one of these MoNoculi are to be found upon it. Quare, - Have we not in these vermes a provision made by the Author of Nature for forcing the salmon from the sea into our rivers, and from the rivers back again into the sea?

\section{Inherited Memory}

YOU.R correspondent "A. B." has propounded a theory which would satisfactorily explain a good many facts in natural history which have hitherto been extremely perplexing. I am strongly inclined to believe that in some of our birds, at any rate, the knowledge of localities is inherited. About thirty years ago I lived at a farmhouse, my father's home; the house stood alone in the country; my father also occupied some premises in a village, about half a mile distant. On these premises there was a large, very old dove-cot containing blue rock pigeons.

My brothers and I wished to establish a similar dove-cot at the farm, and prepared a suitable room for the purpose. In the first instance we caught, one winter's night, about fifty of the old rock pigeons; these we contined for five or six weeks, but when liberated they of course flew straight home. We next took a number of fledged young ones out of the nests. These had never been outside the old dove-cot, but when sufficiently strong they all flew away, as the old ones had done.

Discouraged, but still determined to succeed, we next bought a number of tame pigeons, and when they began to sit we put eggs of blue rocks under them, taking their own eggs away. Several were reared; but as soon as they were strong enough to dispense with the care of their foster-mothers, they one after another deserted them and returned to the ancestral dove-cot. A few years after this the premises where the old dove-cot was situated were altered, and the way into the dove-cot quite stopped up. The pigeons were sold and driven away.

For nearly twenty years blue rocks continued to visit the old premises. Some of them built on a ledge in an old gateway, that being the place in which it was possible for them to find nest-room the nearest to the old dove-cot. These occurrences

\footnotetext{
${ }^{2}$ Br. Zool. iii. 4 to ed., p. 252.
}

seem to point to remembrance of localities in the race as well as in individuals, and "inherited memory" would, I think, best account for all the facts of the case.

The Gynsills, Leicester

\section{A Golden Eagle and a Decoy-Audacity of a Hawk}

WhILST staying a few days at Manhattan, a little town in Kansas, I spent some hours in the office of a dentist, Dr. C. Blackley, who is also an ornithologist, having stuffed a goodly number of the birds of the state. He was then occupied with a fine specimen of the common pelican (Pelicanus communis) one of a flock of over a thousand that passed over the town in the month of April, some of them alighting in the neighbouring marshes. These birds are not unfrequent visitors to these far inland regions, and I have known them shot and brought to me from the alkali lakes in Colorado, both regions from 600 to 800 miles from the sea. The doctor told me an amusing incident of a day's wild goose shooting in the vicinity. He took with him to one of the ponds frequented by wild geese, a stuffed specimen of the Canada goose, to act as a decoy. Having firmly planted his bird in the sand with its wooden platform well covered over, he lay behind the bushes awaiting a shot. Suddenly there was a rush of wings, and like a flash of lightning a golden eagle swept down on the decoy, knocking the bird over, and tearing out some of the stuffing. The eagle then sat down near his prey, staring with amazement at its remarkably quiescent character, as well as at the strange wooden appendage attached to its claws. Deeming there was something uncanny about such a goose, and there might be danger in the neighbourhood, he prudently flew away. Unfortunately a branch of a tree prevented the sports. man from shooting the marauder.

(I can vouch for the truth of this story; the doctor showed the goose and where it had been struck).

A few days after this, when in the village of Morrison, Colorado, I was struck with the audacity of one of our smallest hawks. I was standing on a lumber pile in the middle of the street, when I heard a scuffling of wings, and a squeaking; the latter proceeded from a small prairie squirrel, about the size of a rat, who was making the best of his way to a hole in the lumber, hotly pursued by a tiny hawk, whose body was no larger than that of his prey. The squirrel just escaped into the hole by the tip of his tail, the hawk unable to stop the impetus of its onset, dashing right against the lumberpile, within six feet of where I was standing. I jumped down in pursuit, but totally regardless of my presence, the plucky little bird made another swoop at his prey, who had again made a sally from another hole. I knocked the hawk down this time with my hat, and the squirrel escaped under the wood pile. This took place in the centre of a little village street, with bystanders within a few yards of the occurrence.

The hawk resembled the female sparrow.hawk (Falco sparverius).

School of Mines, Golden City, Colorado

A. LAKIS

\section{INTELLECT IN BRUTES}

NOW that the discussion on this subject in NATURE seems to be running dry, perhaps a few concluding remarks by one who has not hitherto taken any part in it may be admitted.

The discussion was started by $\mathrm{Mr}$. Nicols recording a case of the gnawing of water-pipes by rats. This is not at all an unusual thing for rats to do, and I cannot see that the fact of their doing so, in order to obtain the water, would imply so incredible an amount of sagacity as some of the other writers in NATURE appear to suppose. The water can be heard within the pipe, and if the rats are thirsty, it seems a sufficiently simple device to gnaw the pipe. Of course it may be an open question whether they gnaw the pipe for this purpose, or for the mere sake of gnawing, or for any other purpose; but that a rat should have sufficient intelligence to gnaw through a water-pipe, supposing the animal to require water obtained in this way, I think there can be no doubt.

The discussion was enlivened by $\mathrm{Mr}$. Henslow introduc. ing certain general propositions as to the features wherein animal intelligence differs essentially from human, and it 